\title{
COMPARATIVE EFFICACY OF PHYTASE FROM FISH GUT BACTERIA AND A COMMER- CIALLY AVAILABLE PHYTASE IN IMPROVING THE NUTRITIVE VALUE OF SESAME OILSEED MEAL IN FORMULATED DIETS FOR FINGERLINGS OF ROHU, LABEO ROHITA (ACTINOPTERYGII: CYPRINIFORMES: CYPRINIDAE)
}

\author{
Tanami ROY, Suhas K. DAN, Goutam BANERJEE, Ankita NANDI, Pinki GHOSH, \\ and Arun K. RAY* \\ Fisheries Laboratory, Department of Zoology, Visva-Bharati University, Santiniketan-731235, West Bengal, India
}

Roy T., Dan S.K., Banerjee G., Nandi A., Ghosh P., Ray A.K. 2016. Comparative efficacy of phytase from fish gut bacteria and a commercially available phytase in improving the nutritive value of sesame oilseed meal in formulated diets for fingerlings of rohu, Labeo rohita (Actinopterygii: Cypriniformes: Cyprinidae). Acta Ichthyol. Piscat. 46 (1): 9-23.

Background. Phytate (myo-inositol 1,2,3,4,5,6-hexakis-dihydrogen phosphate) is the main storage form of phosphorus (P) and up to $80 \%$ of the total $\mathrm{P}$ content in plants remains unavailable to fish due to lack of intestinal phytases for efficient phytate hydrolysis. The inclusion of microbial phytase in the feed is an approach to increase phytate phosphorus bioavailability. In the presently reported study, a comparison of the efficacy of phytase produced by fish gut bacterial strain, Bacillus licheniformis LF1 and a commercially available phytase, BiophosTS in improving the nutritive value of sesame (Sesamum indicum) oilseed meal (SOM) was evaluated in the diet for fingerlings of rohu, Labeo rohita (Hamilton, 1822).

Materials and methods. Eleven isonitrogenous (approximately $35 \%$ crude protein) and isocaloric $\left(17.58 \mathrm{~kJ} \cdot \mathrm{g}^{-1}\right.$ gross energy) experimental diets were formulated with the same basal diet containing raw sesame oilseed meal (D1) or oilseed meal pretreated with phytase from the fish gut bacterial strain, B. licheniformis LF1 (D2-D6) and commercially available phytase, Biophos-TS (D7-D11) at 10, 20, 30, 40, and $50 \mathrm{FTU} \cdot \mathrm{kg}^{-1}$ and fed to rohu fingerlings (mean initial weight $1.85 \pm 0.52 \mathrm{~g}$ ) for 80 days.

Results. Fermentation of oilseed meal significantly reduced the crude fibre content and anti-nutritional factors tannins and phytic acid, and enhanced mineral concentration. In terms of growth, feed conversion ratio, and protein efficiency ratio, diets containing sesame oilseed meal pretreated with Biophos-TS at a concentration of $30 \mathrm{FTU} \cdot \mathrm{kg}^{-1}$ and with strain LF1 at a concentration of $40 \mathrm{FTU} \cdot \mathrm{kg}^{-1}$ resulted in a significantly $(P<0.05)$ better performance of rohu fingerlings. The apparent digestibility of protein, lipid, ash and minerals was significantly $(P<0.05)$ higher in fish fed diets D9 and D5 in comparison to those fed reference diet $(\mathrm{RD})$. The crude protein, crude lipid, and ash contents of fish carcass were highest in fish fed diet D9, which was not significantly $(P<0.05)$ different from those in the group of fish fed diet D5. Pretreatment of diets with phytase reduced faecal P levels.

Conclusion. Comparison of the efficacy of phytase produced by fish gut bacteria with commercially available phytase indicated no significant difference in performance of rohu fingerlings in terms of growth and nutrient and mineral utilization.

Keywords: growth performance, mineral utilization, phytase, plant ingredient, aquafeed, Indian major carp

\section{INTRODUCTION}

Unlike most domesticated farm animals, the majority of fish species generally require higher levels of dietary protein for optimum growth. High quality fish meal, with amino acid profile that matched the fish's requirement pattern is therefore, commonly used at high levels. However, the concomitant rise in its price, uncertain availability, and fluctuating quality have led to the search for alternative protein sources for fish feed to sustain fish production. Many leguminous oilseeds have been reported as feeds in fish culture, and the use of plant protein sources to completely or partially replace fish meal in fish diets has been reported in a number of studies (Hardy 2010, Nang Thu et al. 2011, Roy et al. 2014). From the results of these studies, it is quite clear that plant protein cannot be employed as the sole source of dietary protein, and the

* Correspondence: Prof. Arun Kumar Ray, Fisheries Laboratory, Department of Zoology, Visva-Bharati University, Santiniketan-731235, West Bengal, India, phone: (+91) 3463 264620, e-mail: (AKR) rayarun.ray@gmail.com, (TR) tanamiarc@gmail.com, (SKD) dansuhas@gmail.com, (GB) banerjee.goutam3@gmail.com, (AN) tua.ankita@gmail.com, (PG)pinkighosh18@yahoo.in. 
maximum recommended level of inclusion appears to be between $20 \%$ and $30 \%$ of the diet (Hardy and Barrows 2008). One of the major problems associated with the use of plant proteins in fish feed is the presence of antinutritional factors, which are endogenous compounds in feedstuffs that may reduce feed intake, growth, nutrient digestibility and utilization, affect the function of internal organs, or alter disease resistance. In plant feedstuffs, phytate (myo-inositol 1,2,3,4,5,6-hexakis-dihydrogen phosphate) is the main storage form of phosphorus (P) (Krogdahl et al. 2010, Hardy 2010) and up to $80 \%$ of the total $\mathrm{P}$ content in plants may be present in the form of phytate and is practically not available for monogastric or agastric aquatic animals (Anonymous 1993) due to lack of intestinal phytases for efficient phytate hydrolysis (Nwanna and Schwarz 2007, Rao et al. 2009, Hardy 2010).

Phytase (E.C.3.1.3.8. myo-inositol hexaphosphate phosphohydrolase) is a hydrolytic enzyme that initiates the release of phosphate from phytic acid, which is the predominant form of phosphorus in cereal grains, oilseeds, and legumes (Cao et al. 2007, Huang et al. 2009). The presence of phytate in feed is undesirable as it chelates nutritionally important divalent cations like potassium, magnesium, zinc, iron, calcium, and copper, and proteins and amino acids, thereby rendering them biologically unavailable to the animal (Sardar et al. 2007, Afinah et al. 2010, Krogdahl et al. 2010). Phytic acid in the form of phytate also inhibits digestive enzymes in fish (Khan and Ghosh 2013). Thus, the inclusion of plant proteins in fish diets may cause increased phosphorus discharge into the environment and a reduction in growth resulting from the decreased bioavailability of minerals (Cao et al. 2007, 2008). The phytate phosphorus is excreted into the environment and is acted upon by microorganisms that release the phosphorus, causing pollution in terms of algal growth (Cao et al. 2007, 2008). Roy et al. (2009) first confirmed the existence of phytase-producing bacteria in the gastrointestinal tracts of fish. The inclusion of microbial phytase in the feed is an approach to increase phytate phosphorus bioavailability (Sardar et al. 2007, Cao et al. 2008, Khan and Ghosh 2012). Das and Ghosh (2015) also reported efficacy of sesame oil cake after bioprocessing through fermentation with a phytase-producing fish gut bacterium. Roy et al. (2014) assessed the role of phytase-producing fish gut bacteria in enhancing the nutritive value of sesame (Sesamum indicum) seed meal incorporated diets for rohu fingerlings and increasing the bioavailability of nutrients and minerals. There are several reports regarding the efficacy of phytase on growth performance, body composition and phosphorus utilization by the fish fed diets pretreated with microbial phytase (Sugiura et al. 2001, Debnath et al. 2005, Baruah et al. 2007a, 2007b, Cao et al. 2008, Roy et al. 2014, Das and Ghosh 2015), but the report based on the comparison of the efficacy of phytase produced by fish gut bacteria and commercially available phytase is lacking.

It is clear that supplemental phytase can enhance the digestibility and bio-availability of phosphorus, nitrogen and other minerals, reduce the amount of inorganic-P supplement to maximize growth and bone mineralization, and markedly decrease P load to aquatic environment (Cao et al. 2007, Morales et al. 2014, Yoo and Bai 2014). The optimum doses of phytase to replace inorganic $\mathrm{P}$ have not been evaluated in fish diets. Accordingly, further investigations about phytase application in fish feed are largely needed.

In an earlier study in our laboratory with the phytase producing fish gut bacterial strain, Bacillus licheniformis LF1, we observed that this particular strain improved the nutritive value of sesame oilseed meal in the formulated diets for fingerlings of rohu, Labeo rohita (Hamilton, 1822) (see Roy et al. 2014). In the presently reported study, a comparative evaluation was done to assess the efficacy of phytase produced by fish gut bacteria (Bacillus licheniformis LF1, isolated from the foregut region of L. rohita) and the commercially available phytase, Biophos-TS (Biochem Health Care, Mumbai, India, derived from fungus Aspergillus niger) in improving the nutritive value of sesame (Sesamum indicum) oilseed meal incorporated diets and increasing the bioavailability of nutrients and minerals like $\mathrm{P}, \mathrm{Ca}, \mathrm{Mn}, \mathrm{Fe}$, and $\mathrm{Cu}$ in the Indian major carp, rohu, Labeo rohita fingerlings through feeding trial.

\section{MATERIALS AND METHODS}

Microorganism used. The phytase-producing bacteria, Bacillus licheniformis LF1 (GenBank Accession Number: DQ351932) isolated from the proximal intestine of the Indian major carp, rohu, Labeo rohita (see Roy et al. 2009) was used for fermentation of sesame seed meal.

Preparation of bacterial culture and fermentation of oilseed meal. The phytase-producing bacterial strain B. licheniformis LF1 was cultured in shake bottles in $4 \%$ tryptone soya broth (Hi-Media, Mumbai, India) for seed culture at $37 \pm 1^{\circ} \mathrm{C}$ for $24 \mathrm{~h}$ to obtain a mean viable count of $10^{7}$ cells $\cdot \mathrm{mL}^{-1}$ broth. This seed culture was transferred to the sterilized modified phytase screening medium with optimum carbon, nitrogen, and vitamin sources and incubated under optimized culture conditions for the isolate LF1 as described by Roy et al. (2013). After $72 \mathrm{~h}$ of incubation, the bacterial culture was centrifuged at $10000 \times g$ for $10 \mathrm{~min}$ and the bacterial cells were discarded. The phytase activity of the culture supernatant was determined following Engelen et al. (1994) and the Fomazine Turbidity Unit (FTU) per mL of bacterial enzyme was calculated [1 FTU is defined as the amount of phytase that liberates $1 \mu \mathrm{mol}$ of inorganic phosphorus from $0.0051 \mathrm{~mol} \cdot \mathrm{L}^{-1}$ of sodium phytate per $\min$ at $37^{\circ} \mathrm{C}$ and $\mathrm{pH}$ 5.5]. The enzyme extract was stored at $-20^{\circ} \mathrm{C}$ until further use. The sesame oilseed meals were sundried, finely ground, and passed through a fine meshed sieve to ensure homogeneity. The oilseed meal was sterilized by autoclaving and fermented in vitro with the bacterial phytase and commercially available phytase, Biophos-TS (Biochem Health Care Limited, Mumbai, India) at different concentrations $(10,20,30,40$, and 50 $\mathrm{FTU} \cdot \mathrm{kg}^{-1}$ ) at $37 \pm 1^{\circ} \mathrm{C}$ for $24 \mathrm{~h}$ prior to their incorporation into fish diets. The proximate composition, anti-nutritional factors (tannin and phytic acid) and mineral concentration of sesame oilseed meal were determined both before and after fermentation (Tables 1 and 2). 


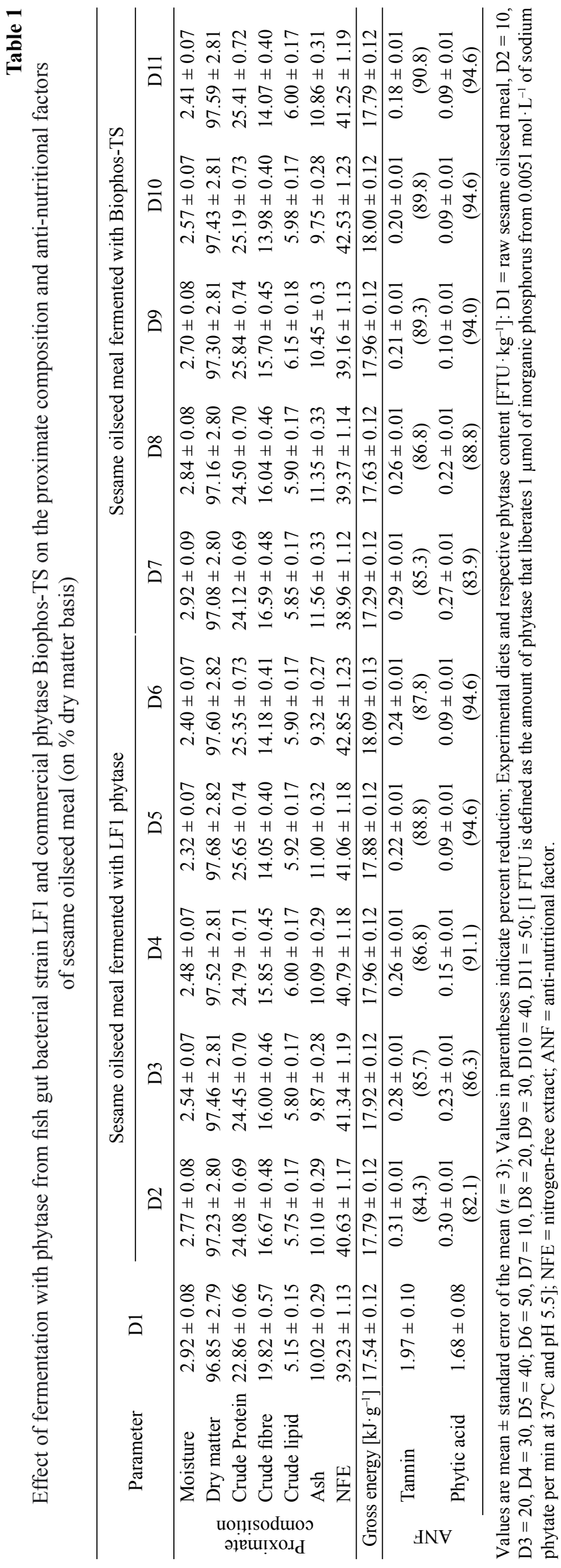

$\frac{N}{\frac{0}{0}}$

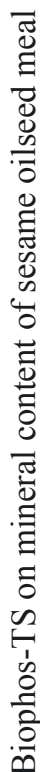

宽

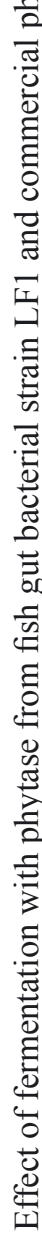

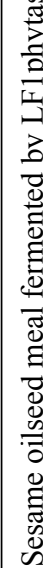

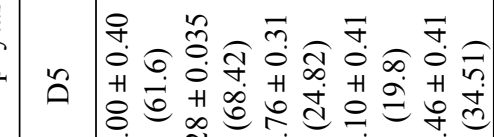

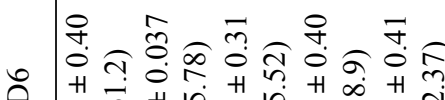

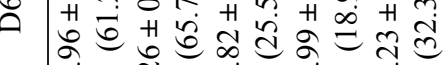

$\leadsto \stackrel{-}{\square} \dot{I}$

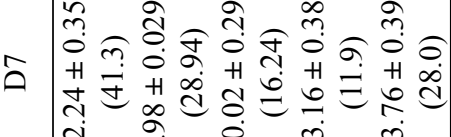

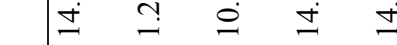

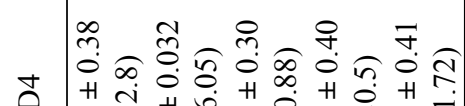

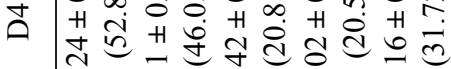

$\doteq \exists \quad \dot{ \pm}$

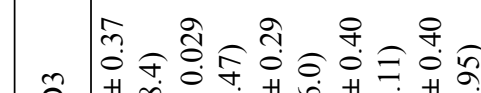

กิ

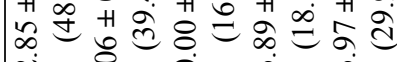

(n)

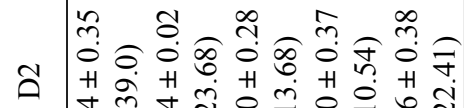

स के सं वें

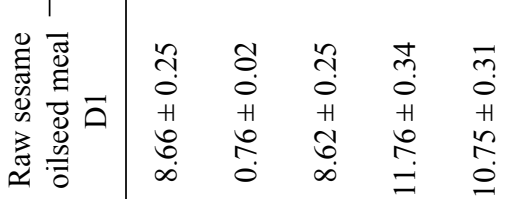

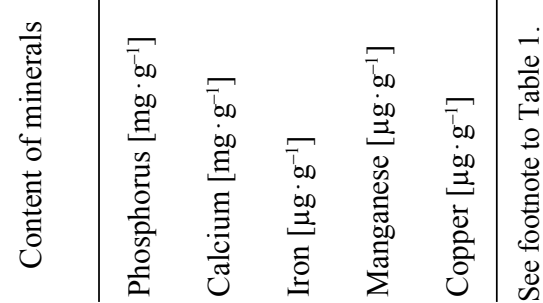


Experimental diets. Eleven isonitrogenous (35\% crude protein approximately) and isocaloric $\left(17.58 \mathrm{~kJ} \cdot \mathrm{g}^{-1}\right.$ gross energy approximately) experimental diets were prepared with a basal diet containing raw sesame oilseed meal (D1), experimental diets (D2-D6) containing sesame oilseed meal pretreated with bacterial phytase at different concentrations $\left(\mathrm{D} 2=10 \mathrm{FTU} \cdot \mathrm{kg}^{-1} ; \mathrm{D} 3=20 \mathrm{FTU} \cdot \mathrm{kg}^{-1}\right.$; $\mathrm{D} 4=30 \mathrm{FTU} \cdot \mathrm{kg}^{-1}$; D5 = $40 \mathrm{FTU} \cdot \mathrm{kg}^{-1}$; D6 = $50 \mathrm{FTU} \cdot$ $\mathrm{kg}^{-1}$ ) and diets D7 through D11, containing sesame oilseed meal treated with commercially available phytase, Biophos-TS at different concentrations (D7 $=10 \mathrm{FTU} \cdot \mathrm{kg}^{-}$ '; D8 = $20 \mathrm{FTU} \cdot \mathrm{kg}^{-1}$; D9 $=30 \mathrm{FTU} \cdot \mathrm{kg}^{-1}$; D10 = $40 \mathrm{FTU}$. $\mathrm{kg}^{-1}$; D11 $\left.=50 \mathrm{FTU} \cdot \mathrm{kg}^{-1}\right)$. The ingredient compositions of the experimental diets are given in Table 3. A diet containing fish meal as the main protein source was used as the reference diet (RD). To each of the formulated diet $1 \%$ chromic oxide was added as digestibility marker. The diets were prepared in pelleted form using $0.5 \%$ carboxymethylcellulose as binder and the pellets were dried in oven and stored in airtight containers in a refrigerator at $4^{\circ} \mathrm{C}$ until used. The proximate composition of experimental diets is presented in Table 4.

Experimental design. The feeding trial was conducted in flow-through $90 \mathrm{~L}$ circular fibre-glass tanks for 80 days under laboratory conditions. Each tank was supplemented with unchlorinated water from a deep tube well with continuous aeration. Rohu, Labeo rohita, fingerlings were obtained from a local fish seed dealer and acclimatized for 15 days and fed with a mixture of rice bran and mustard oil cake. The fingerlings (mean initial weight $1.85 \pm 0.52$ g) were randomly distributed in the fibre-glass tanks at a stocking density of 15 fish per tank with three replicates for each dietary treatment. Fish were fed once daily at $1000 \mathrm{~h}$ at a fixed feeding rate of $3 \%$ of total body weight per day. To determine the feed consumption, any leftover feed was collected $6 \mathrm{~h}$ after each feeding and weighed after oven drying. The digestibility study was conducted separately in static aquaria. The faecal samples were collected everyday in the morning by siphoning $17 \mathrm{~h}$ after removal of the uneaten feed following the "immediate pipetting" method outlined by Spyridakis et al. (1989) from three replicates of each dietary treatment. The faeces naturally released by the fish could be easily detected and were immediately removed from the water with a glass canula. Pooled samples of uneaten feed and faecal matters for each dietary treatment were dried at $55^{\circ} \mathrm{C}$ and stored in a refrigerator for subsequent analysis. At the termination of 80-day experiment the fish were weighed and analysed for carcass composition. There was no mortality of fish during the feeding trial. The water quality parameters from each tank were monitored each week throughout the experimental period for temperature, $\mathrm{pH}$, dissolved oxygen, and total alkalinity. The ranges of water quality parameters were: temperature, $29-32^{\circ} \mathrm{C} ; \mathrm{pH}, 7-7.8$; dissolved oxygen, $4.6-5.5 \mathrm{mg} \cdot \mathrm{L}^{-1}$; and alkalinity, 155 $170 \mathrm{mg} \cdot \mathrm{L}^{-1}$.

Chemical analyses and data collection. Feed ingredients, experimental diets, faecal samples, and fish carcass (at the beginning and after the termination of experiment) were analysed for proximate composition according to AOAC procedures (Anonymous 1990) and the procedures as described by Roy et al. (2014).

Tannin and phytic acid contents in both fermented and raw sesame oilseed meal were determined following Schanderi (1970) and Wheeler and Ferrel (1971), respectively. Phosphorus and calcium contents in the diets, faecal samples, and carcass were estimated following Fiske and Subba Row as described by Hawk (1960) and Clark-Collip modification of Kramer-Trisdall method as described by Hawk (1960), respectively. Mn, Cu, and Fe contents were estimated using an atomic absorption spectrophotometer (Electronics Corporation of India,

Ingredient composition of experimental diets ( $\%$ of dry matter basis)

Table 3

\begin{tabular}{|c|c|c|c|c|c|c|c|c|c|c|c|c|}
\hline \multirow{2}{*}{ Ingredient } & \multirow{2}{*}{$\begin{array}{c}\text { Reference } \\
\text { diet } \\
\text { RD }\end{array}$} & \multirow{2}{*}{$\begin{array}{c}\text { Sesame } \\
\text { diet } \\
\text { D1 }\end{array}$} & \multicolumn{5}{|c|}{$\begin{array}{l}\text { Diets with sesame seed meal } \\
\text { fermented by LF1 strain }\end{array}$} & \multicolumn{5}{|c|}{$\begin{array}{l}\text { Diets with sesame seed meal } \\
\text { fermented by Biophos-TS }\end{array}$} \\
\hline & & & D2 & D3 & D4 & D5 & D6 & D7 & D8 & D9 & D10 & D11 \\
\hline Fish meal & 40.0 & 31.0 & 31.0 & 31.0 & 31.0 & 31.0 & 31.0 & 31.0 & 31.0 & 31.0 & 31.0 & 31.0 \\
\hline Mustard oil cake & 24.0 & 27.0 & 27.0 & 27.0 & 27.0 & 27.0 & 27.0 & 27.0 & 27.0 & 27.0 & 27.0 & 27.0 \\
\hline Rice bran & 33.0 & 9.0 & 9.0 & 9.0 & 9.0 & 9.0 & 9.0 & 9.0 & 9.0 & 9.0 & 9.0 & 9.0 \\
\hline Sesame seed meal & - & 30.0 & 30.0 & 30.0 & 30.0 & 30.0 & 30.0 & 30.0 & 30.0 & 30.0 & 30.0 & 30.0 \\
\hline Soybean oil & 0.5 & 0.5 & 0.5 & 0.5 & 0.5 & 0.5 & 0.5 & 0.5 & 0.5 & 0.5 & 0.5 & 0.5 \\
\hline Cod liver oil & 0.5 & 0.5 & 0.5 & 0.5 & 0.5 & 0.5 & 0.5 & 0.5 & 0.5 & 0.5 & 0.5 & 0.5 \\
\hline Vitamin Premix ${ }^{\mathrm{a}}$ & 1.0 & 1.0 & 1.0 & 1.0 & 1.0 & 1.0 & 1.0 & 1.0 & 1.0 & 1.0 & 1.0 & 1.0 \\
\hline Chromic oxide & 1.0 & 1.0 & 1.0 & 1.0 & 1.0 & 1.0 & 1.0 & 1.0 & 1.0 & 1.0 & 1.0 & 1.0 \\
\hline Citric acid ${ }^{\mathrm{b}}$ & - & 0.5 & 0.5 & 0.5 & 0.5 & 0.5 & 0.5 & 0.5 & 0.5 & 0.5 & 0.5 & 0.5 \\
\hline $\begin{array}{l}\text { Dietary phytase } \\
{[\mathrm{FTU} \cdot \mathrm{kg}-1]}\end{array}$ & - & - & 10 & 20 & 30 & 40 & 50 & 10 & 20 & 30 & 40 & 50 \\
\hline
\end{tabular}

Sesame diet $=$ diet with raw sesame seed meal; ${ }^{a}$ Vitamin and mineral mixture (Vitaminetes forte, Roche Products India Private Limited, Mumbai, India); ${ }^{b}$ Citric acid $(0.5 \%)$ was added to the experimental diets for maintaining the $\mathrm{pH}$ at 5.5 ; Experimental diets and respective phytase content $\left[\mathrm{FTU} \cdot \mathrm{kg}^{-1}\right]: \mathrm{D} 2=10$, D3 = 20, D4 = 30, D5 = 40; D6 = 50, D7 = 10, D8 = 20, D9 = 30, D10 = 40, D11 = 50; $[1 \mathrm{FTU}$ is defined as the amount of phytase that liberates $1 \mu \mathrm{mol}$ of inorganic phosphorus from $0.0051 \mathrm{~mol} \cdot \mathrm{L}^{-1}$ of sodium phytate per min at $37^{\circ} \mathrm{C}$ and $\mathrm{pH}$ 5.5]. 
Hyderabad, Andhra Pradesh, India, Model: AAS4129). The intestinal phytase activity was estimated following the method of Engelen et al. (1994). One phytase unit (U) was defined as the amount of enzyme per $\mathrm{mL}$ of culture filtrate that released $1 \mu \mathrm{g}$ of inorganic phosphorus per min. The water quality parameters were monitored following the methods outlined by APHA (Anonymous 1985).

Fish performance in terms of weight gain [\%], specific growth rate $(\mathrm{SGR})\left[\% \cdot\right.$ day $\left.^{-1}\right]$, feed conversion ratio (FCR), protein efficiency ratio (PER), and apparent net protein utilization (ANPU) was determined using the standard formulae (Steffens 1989).

Statistical analysis. Statistical analysis was done by one-way analysis of variance (ANOVA) using MS-Excel software (Microsoft Office 2007). Mean difference between treatments were tested for significance at $P<0.05$ and comparisons were made by Duncan's multiple range test (Duncan 1955) to find out which treatment differed significantly from the other in respect of growth, carcass composition, digestibility, and general performance of the fish.

\section{RESULTS}

Effect of fermentation of sesame seed meal on proximate composition, anti-nutritional factors, and mineral concentration. Fermentation with the phytase from the fish gut bacterial strain Bacillus licheniformis LF1 and commercially available phytase, Biophos-TS resulted in reduction of anti-nutritional factors, increase in crude protein and crude lipid levels (Table 1). The level of crude protein in fermented sesame oil seed meal increased from $22.86 \%$ to $25.65 \%$ for LF1 (40 FTU $\cdot \mathrm{kg}^{-1}$ ) and $25.84 \%$ for Biophos-TS (30 FTU $\cdot \mathrm{kg}^{-1}$ ), whereas, crude lipid level increased from $5.15 \%$ to $6.00 \%$ for LF1 (30 FTU $\cdot \mathrm{kg}^{-1}$ ) and $6.15 \%$ for Biophos-TS (30 FTU $\cdot \mathrm{kg}^{-1}$ ). In both the cases, the level of free amino acids increased from $0.27 \%$ to $0.52 \%$. Fermentation of sesame oil seed meal also resulted in significant increase in its mineral contents (Table 2).

Fish growth performance and feed utilization. The growth performance and feed utilization of rohu fingerlings are depicted in Table 5. The mean final weight of the fish increased significantly from the initial value in all dietary treatments. Fish reared on diet D9 (containing sesame oilseed meal fermented with Biophos-TS at a concentration of $30 \mathrm{FTU} \cdot \mathrm{kg}^{-1}$ ) and D5 (containing sesame oilseed meal fermented with LF1 strain at a concentration of $40 \mathrm{FTU} \cdot \mathrm{kg}^{-1}$ ) showed good performance in terms of live weight gain (\%), specific growth rate (SGR), protein efficiency ratio (PER), and apparent net protein utilization (ANPU). However, live weight gain (\%) and specific growth rate (SGR), were not significantly $(P<0.05)$ different from the group of fish fed diet D6 (containing oilseed meal fermented with LF1 strain at a concentration of $50 \mathrm{FTU} \cdot \mathrm{kg}^{-1}$ ) and D10 (containing oilseed meal fermented with Biophos-TS at a concentration of $40 \mathrm{FTU} \cdot \mathrm{kg}^{-1}$ ). Feed conversion ratio (FCR) was lowest for diet D9 which was not significantly $(P<0.05)$ different from that for the fish fed diet D5 and D10, FCR was highest for the groups of fish fed diet D1 that was not significantly $(P<0.05)$ different from that for the groups of fish fed diets $\mathrm{RD}$ and $\mathrm{D} 2$.

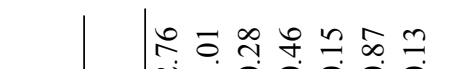

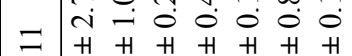

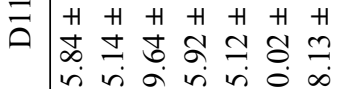

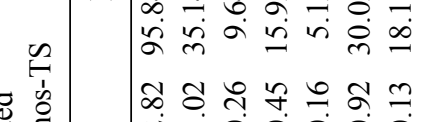

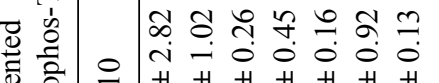
을 $\begin{array}{llllll}H & H & H & H & H & H\end{array}$

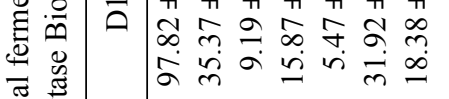
丞 己心

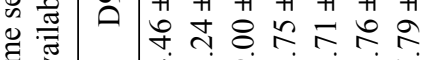
मे in a in is

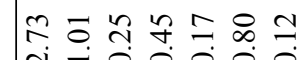

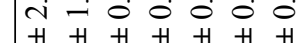

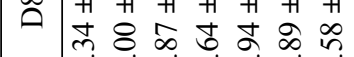

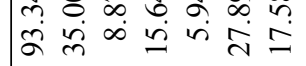
के

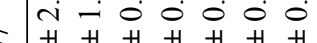

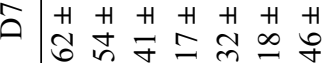
๙ู่ $\infty$ in

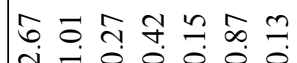
$\begin{array}{lllllll}1 & 0 & 0 & 0 & 0 & 0 & 0 \\ H & H & H & H & H & H & H\end{array}$ - 20 元

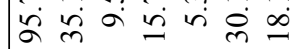
ㅇำ

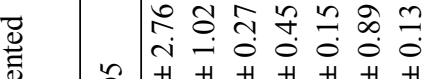

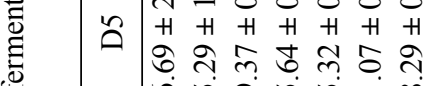
巳 $\quad$ क 节

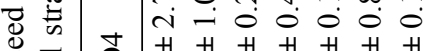

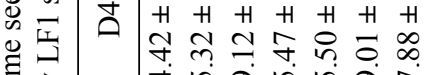

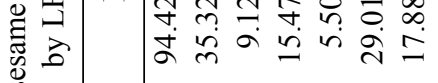
=

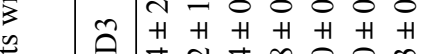

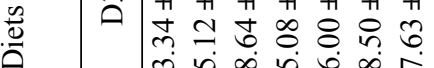
बू

ชื

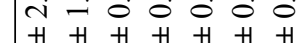

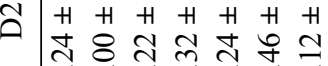
సָ

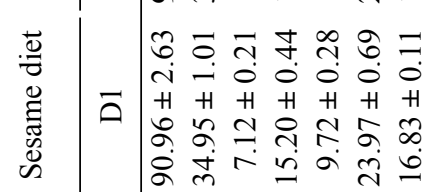


Apparent nutrient and mineral digestibility. The apparent digestibility of protein, lipid, and ash were better in fish fed diets D9 and D5, which were not significantly $(P<0.05)$ different in the group of fish fed diets D6, D10, and D11. Maximum dry matter digestibility was recorded in fish fed diet D2 and was not significantly different from that in the fish fed reference diet (Fig. 1). Maximum phosphorus, calcium, manganese, copper, and iron digestibility was recorded in the group of fish fed diet D9, which was not significantly $(P<0.05)$ different in the groups of fish fed diets D5, D6, and D10 (Figs. 2a and b). Proximate carcass composition. Proximate carcass composition in experimental fish at the termination of the feeding experiment is depicted in Fig. 3. The deposition of carcass protein and lipid was significantly $(P<0.05)$ maximal in fish fed fermented sesame seed meal incorporated diets than the reference diet. The crude protein, crude lipid, and ash contents of fish carcass were highest in fish fed diet D9, which was not significantly $(P<0.05)$ different from those in the group of fish fed diet D5. Mineral concentration in the carcass of experimental fish increased over the initial value in all dietary treatments and an increasing level of phytase was associated with an increase in carcass mineral content (Table 6). The phosphorus, calcium, manganese, copper, and iron contents in the fish carcass were highest for diet D9, which were not significantly $(P<0.05)$ different from those in the group of fish fed diet D5. In case of calcium, no significant $(P<0.05)$ difference was noticed in the fish fed diet D6 (containing sesame oilseed meal fermented with bacterial strain LF1 at a concentration of $50 \mathrm{FTU}$. $\mathrm{kg}^{-1}$ ) and D10 (containing sesame oilseed meal fermented with commercially Biophos-TS at a concentration of $40 \mathrm{FTU} \cdot \mathrm{kg}^{-1}$ ).

Intestinal phytase activity. Intestinal phytase activity in experimental fish at the termination of the feeding experiment is presented in Fig. 4. The intestinal phytase activity increased with increasing level of incorporation of bacterial or commercial phytase in the diets. Intestinal phytase activity was higher in the groups of fish fed fermented oilseed meal incorporated diets in comparison to that fed raw seed meal incorporated diet. The highest phytase activity was recorded in the group of fish fed diet D9 which was not significantly different from that in the groups of fish fed experimental diets D5 and D11.

Faecal phosphorus concentration. The faecal phosphorus concentration was significantly higher in fish fed (Fig. 5) raw sesame seed meal incorporated diet than the reference diet and an increasing level of phytase in the diets was associated with a decrease in faecal phosphorus concentration. Maximum faecal phosphorus concentration was detected in the fish fed diet D1, containing raw sesame oilseed meal.

\section{DISCUSSION}

In the presently reported investigation small fingerlings (mean initial weight $1.85 \pm 0.52 \mathrm{~g}$ ) of Labeo rohita were used to evaluate dietary effect on the growth of the fish. Small fish respond faster than large fish to nutritional variables. Moreover, small fish are more sensitive to diet differences; if small fish are unaffected, it is a safe assumption that larger fish will not be (Lovell 1998). The results of our study indicated that the mean final weight of the fish increased considerably from the initial value in all dietary treatments. The overall growth performance of rohu fingerlings, fed fermented sesame oilseed meal, incorporated diets in both cases were better in comparison to fish fed raw oilseed meal diet. The observation on weight gain in both cases i.e., phytase from fish gut bacteria Bacillus licheniformis LF1 and commercially available phytase Biophos-TS corroborates the findings of Liebert and Portz (2005), who reported that different sources of microbial phytase similarly affected the growth in Nile tilapia, Oreochromis niloticus (Linnaeus, 1758). The differences in the growth performance recorded in this study agree with the report of Nwanna et al. (2005) that common carp, Cyprinus carpio Linnaeus, 1758, reared on phytase treated diets showed a significantly higher weight gain and feed conversion ratio in comparison to the diets without phytase. Growth improvement was also observed in rainbow trout, Oncorhynchus mykiss (Walbaum, 1792) (see Yang et al. 2011); Nile tilapia (Hassaan et al. 2013); zebrafish, Danio rerio (Hamilton, 1822) (see Liu et al. 2013); Australian catfish, Tandanus tandanus (Mitchell, 1838) (see Huynh and Nugegoda 2011); and yellow catfish, Pelteobagrus fulvidraco (Richardson, 1846) (see Zhu et al. 2014) fed phytase supplemented diets. The dietary microbial phytase pre-treatment improved growth in fingerlings of Pangasius pangasius (Hamilton, 1822) (see Debnath et al. 2005). In L. rohita also growth performance was significantly improved on corn gluten meal $(30 \%)$ based experimental diets with graded levels of phytase pre-treatment (Hussain et al. 2011). However, phytase pre-treatment did not improve the growth of rainbow trout fed diets containing canola protein concentrate (Forster et al. 1999), juvenile Korean rock fish, Sebastes schlegeli Hilgendorf, 1880, fed diets containing soybean meal (Yoo et al. 2005) and Atlantic salmon, Salmo salar Linnaeus, 1758 , fed soy protein concentrate treated with graded levels of phytase (Carter and Sajjadi 2011). Nwanna and Schwarz (2007) also found only marginal effects on the mean weight gain, specific growth rate, and feed conversion ratio when common carp was fed with phytase pre-treated diet. This discrepancy may be due to the differences in the phytase pretreatment methods of the feedstuff and also different rearing conditions. Hauler and Carter (1997) reported that phytase stimulated appetite which increased the growth of Atlantic salmon, S. salar. In channel catfish, Ictalurus punctatus (Rafinesque, 1818), also phytase pretreatment stimulated appetite and increased the growth through increased feed intake ( $\mathrm{Li}$ and Robinson 1997). Formation of complex between sesame seed $\alpha$-globulin and sodium phytate has been described as a bi-phasic reaction (Rajendran and Prakash 1993). Initially phytase binds protein through strong electrostatic attractions which is followed by slower protein-protein interactions resulting in precipitation when the protein-phytate complex exceeds a critical size. It appears that phytase 
$\frac{0}{\frac{0}{0}}$

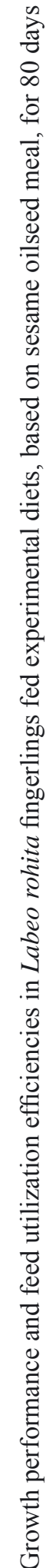$$
\text { . }
$$

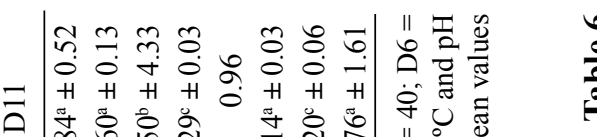

$\infty \overline{\vec{D}}$

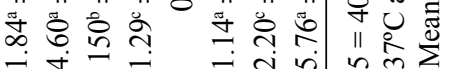
กิ$$
\text { D }
$$$$
\text { 政 }
$$$$
\text { 운 }
$$

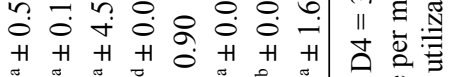

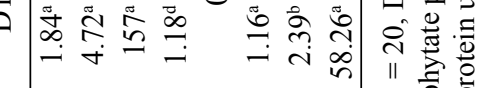

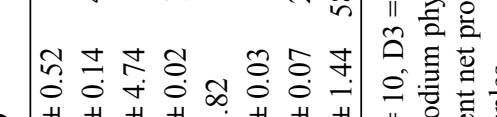

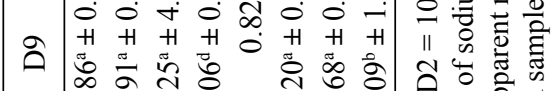

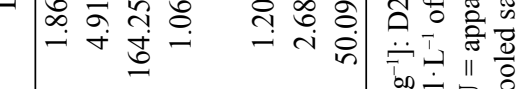

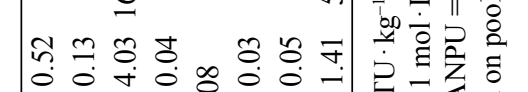

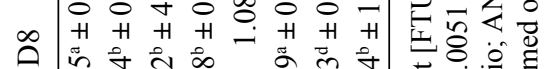

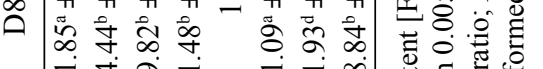$$
\text { - + बें - }
$$

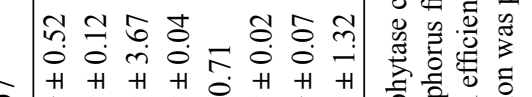$$
\text { กิ }
$$

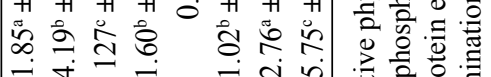$$
\text { 4 } 40 \text { क }
$$

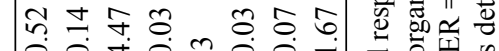

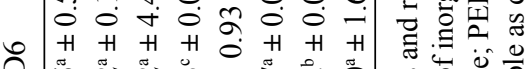$$
\text { ○ी }
$$

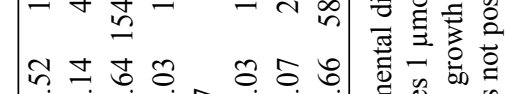

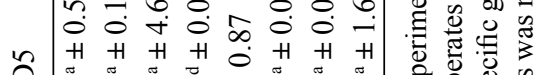

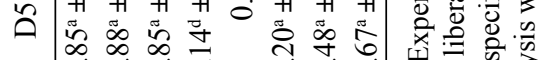

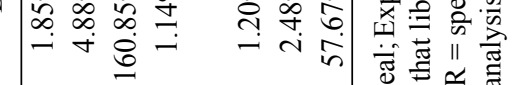$$
\text { กิน }
$$

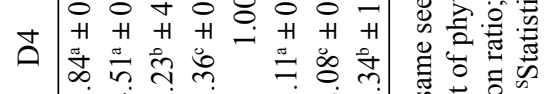$$
\text { - + 守- }- \text { - }
$$

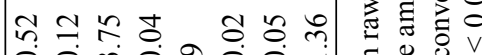

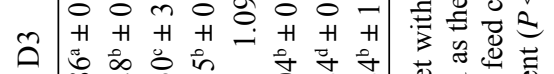

ص|

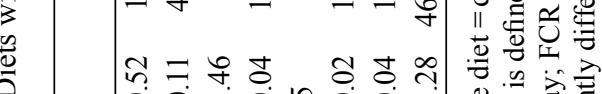

人)

ลิ

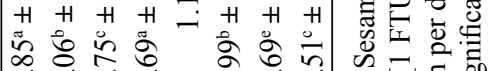

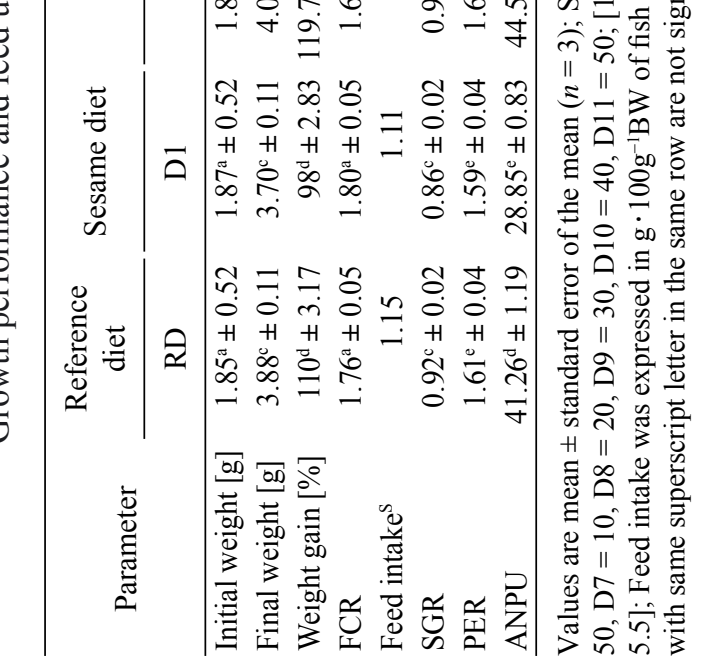

0
$\frac{0}{2}$
$\frac{0}{\pi}$

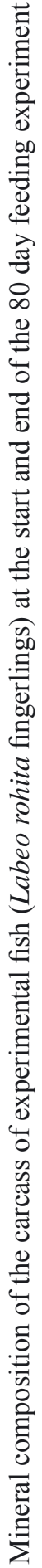

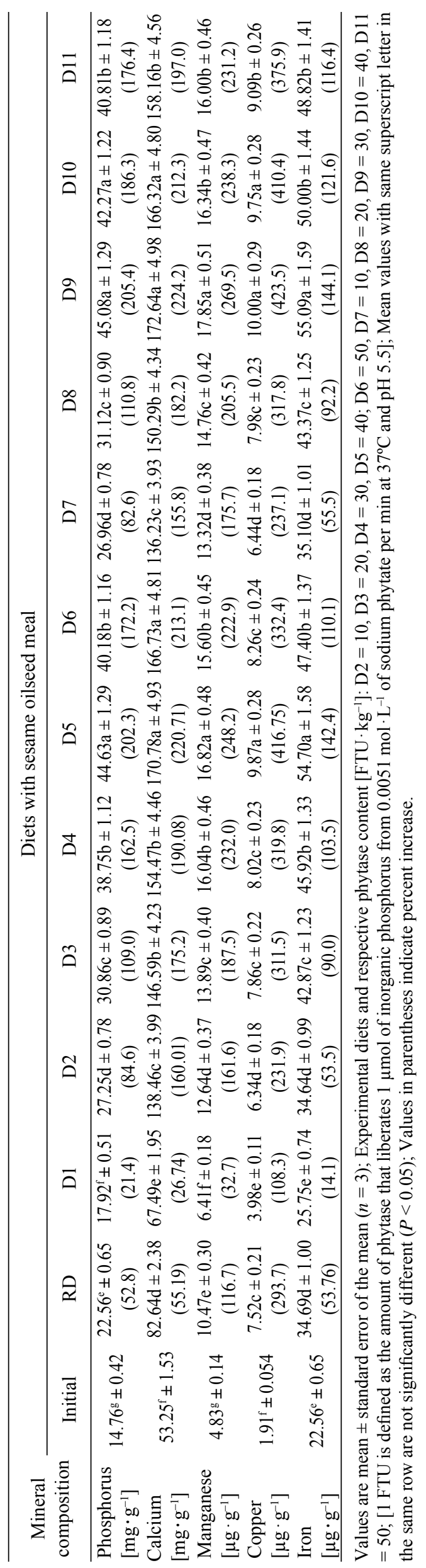




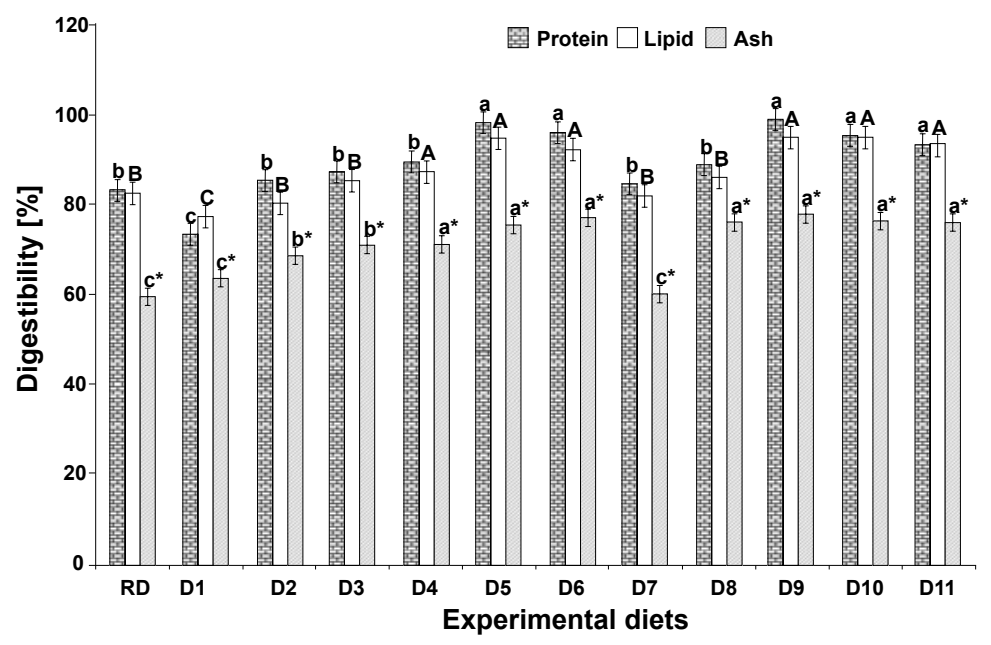

Fig. 1. Apparent nutrient digestibility of Labeo rohita fingerlings fed experimental diets for 80 days; Values are mean \pm standard error of the mean; Error bars show deviation among three replicates; Means with different letters are significantly different $(P<0.05)$; Experimental diets and respective phytase content $\left[\mathrm{FTU} \cdot \mathrm{kg}^{-1}\right]$ : D2 $=10, \mathrm{D} 3=20$, $\mathrm{D} 4=30, \mathrm{D} 5=40 ; \mathrm{D} 6=50, \mathrm{D} 7=10, \mathrm{D} 8=20, \mathrm{D} 9=30, \mathrm{D} 10=40, \mathrm{D} 11=50 ;$ [ $1 \mathrm{FTU}$ is defined as the amount of phytase that liberates $1 \mu \mathrm{mol}$ of inorganic phosphorus from $0.0051 \mathrm{~mol} \cdot \mathrm{L}^{-1}$ of sodium phytate per min at $37^{\circ} \mathrm{C}$ and $\left.\mathrm{pH} 5.5\right]$

(both bacterial and commercial) in the presently reported study partially prevented the formation of protein-phytate complexes by prior hydrolysis of phytate to release protein so that it becomes available for growth. In the presently reported, improvement in growth performance of rohu fingerlings may be attributed to enhanced release of nutrients by breaking down the bonds between phytateprotein complex. Improvement in growth performance of rohu fingerlings may also be attributed to the improved use of phytate-P as well as phytate-bound protein. Feeding rate is important for the growth, feed conversion, nutrient retention efficiency, and chemical composition of fish (Hung and Lutes 1987). An optimum feeding rate is helpful to minimize the feed loss, reduce water pollution, and decrease cost of aquaculture production (Du et al. 2006). In earlier experiments in this laboratory, it was established that rohu fingerlings fed to apparent satiation displayed a feed intake more uniform and close to $3 \% \mathrm{BW} \cdot$ day $^{-1}$ fixed feeding level (Bairagi et al. 2002, 2004, Ramachandran and Ray, 2007, Roy et al. 2014). Therefore, in the presently reported experiment also rohu fingerlings were fed at a fixed feeding rate of $3 \% \mathrm{BW}$. $\mathrm{d}^{-1}$. In our study, the overall growth performance of rohu fingerlings remained low compared to its growth in natural and farm conditions. A similar growth trend has also been reported with other nutritional experiments conducted on Indian major carps including rohu (Ravi and Devaraj 1991, Bairagi et al. 2002, 2004, Benkappa and Varghese 2003, Khan et al. 2012, Roy et al. 2014). As fishes are poikilotherms, drastic change in their surrounding water temperature will influence their metabolic processes, behaviour, migration, growth, reproduction, and survival (Fry 1971, Pörtner 2001). A possible explanation for this lower growth rate could be that Indian major carps are sensitive to environmental conditions and do not attain maximum growth in a confined environment compared with other hardy species such as tilapia and common carp (Benkappa and Varghese 2003). Another possible reason of poor fish growth might be due to low appetite and low feed utilization (Islam 2002).

Dietary protein is the primary source of nitrogen, which is the other enriching nutrient of major concern in aquaculture (Hardy 2010). In this experiment, an increase in body protein accretion and nutrient (crude protein, lipid) digestibility was noticed in rohu fingerlings fed Biophos-TS pre-treated diet, D9. The performance of fish reared on the control and raw oilseed meal incorporated diets were poor compared to fish reared on other experimental diets in terms of weight gain, PER, FCR, deposition of crude protein and lipid in the carcass, and apparent nutrient (crude protein, lipid) digestibility. However, the significant increase in body protein accretion and nutrient (crude protein, lipid) digestibility recorded from this study disagree with the report of Yan et al. (2002), who demonstrated that weight gain and dietary protein utilization of channel catfish were not improved by phytase addition.

It has been shown that the addition of microbial phytase enhanced the availability of various minerals from the plant oilseed meals and improved their absorption. Mineral concentration of the carcass of experimental fish increased over the initial value in all dietary treatments. Although the deposition of phosphorus, manganese, copper, and iron in fish carcass was higher in rohu fingerlings fed Biophos-TS pretreated diet D9, they were not significantly different from those in the fish fed bacterial phytase pretreated diet D5. In the case of calcium deposition, there was no significant difference among the fish fed diets D5, D6, D9, and D10. Biophos-TS pretreated diets showed satisfactory results in terms of phosphorus-, calcium-, manganese-, copper-, and iron digestibility which was not significantly different from those in the fish fed bacterial phytase pretreated diet. 

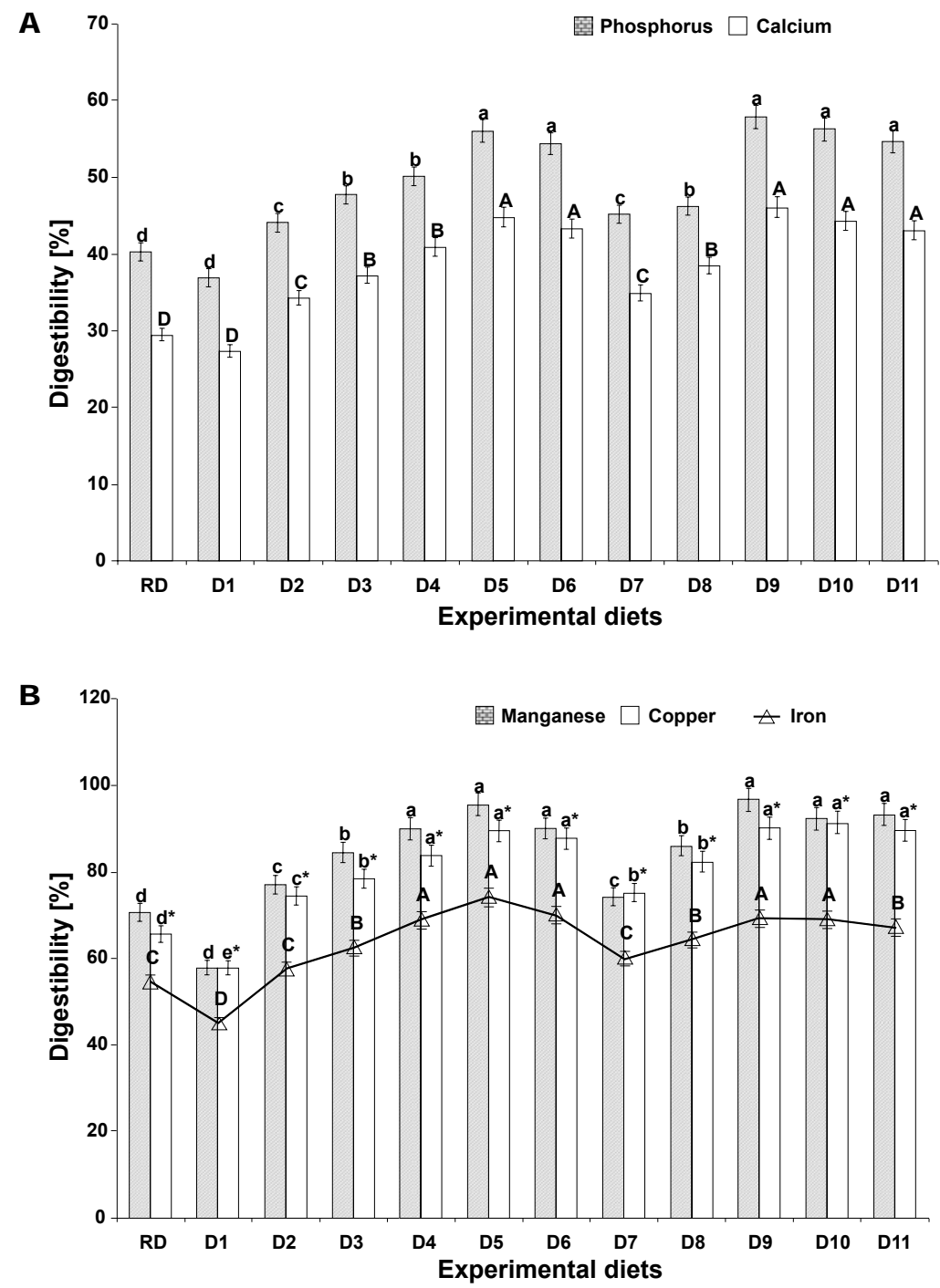

Fig. 2. Apparent digestibility of phosphorus and calcium (A) and manganese, copper, and iron (B) in Labeo rohita fingerlings fed experimental diets for 80 days; Values are mean \pm standard error of the mean; Error bars show deviation among three replicates; Means with different letters are significantly different $(P<0.05)$; Experimental diets and respective phytase content $\left[\mathrm{FTU} \cdot \mathrm{kg}^{-1}\right]: \mathrm{D} 2=10, \mathrm{D} 3=20, \mathrm{D} 4=30, \mathrm{D} 5=40 ; \mathrm{D} 6=50, \mathrm{D} 7=10, \mathrm{D} 8=20, \mathrm{D} 9=30$, $\mathrm{D} 10=40, \mathrm{D} 11=50 ;[1 \mathrm{FTU}$ is defined as the amount of phytase that liberates $1 \mu \mathrm{mol}$ of inorganic phosphorus from $0.0051 \mathrm{~mol} \cdot \mathrm{L}^{-1}$ of sodium phytate per min at $37^{\circ} \mathrm{C}$ and $\left.\mathrm{pH} 5.5\right]$

The phosphorus-, calcium-, manganese-, copper-, and iron digestibility did not show any significant difference among the dietary groups D9, D10, D11, D5, and D6. The results of the presently reported study revealed that fermentation of sesame oilseed meal by phytase from both Biophos-TS and Bacillus licheniformis LF1 significantly increased available mineral contents in feed, indicating that the indigestible phytate-P and also other minerals $(\mathrm{Ca}, \mathrm{Mn}, \mathrm{Fe}$, and $\mathrm{Cu}$ ) might have been successfully converted to available form by phytase. Phytase from fish gut bacteria B. licheniformis LF1 and commercially available phytase Biophos-TS, both possess the ability to liberate bound phytate $\mathrm{P}$, which resulted in increased $\mathrm{P}$ and other mineral digestibility. Improvements in utilization of dietary phosphorus from soybean meal based feedstuffs have been reported in various fish species, such as rainbow trout, Oncorhynchus mykiss (see Sugiura et al. 2001, Yang et al. 2011); Atlantic salmon, Salmo salar (see Storebakken et al. 1998); striped bass, Morone saxatilis (Walbaum, 1792) (see Papatryphon and Soares 2001); European seabass, Dicentrarchus labrax (Linnaeus, 1758) (see Oliva-Teles et al. 1998); common carp, Cyprinus carpio (see Nwanna and Schwarz 2007); Australian catfish, Tandanus tandanus (Huynh and Nugegoda 2011); and juvenile olive flounder, Paralichthys olivaceus (Temminck et Schlegel, 1846) (see Yoo and Bai 2014). Apparent digestibility of phosphorus, calcium, manganese, iron, and zinc from barley, canola meal, wheat, and wheat middling by rainbow trout also has been reported to increase with the addition of phytase (Gatlin and Li 2008). Omnivorous fish species such as channel catfish, Ictalurus punctatus, has been shown to exhibit increased phosphorus utilization from soybean meal based diets with the supplementation of phytase (Yan et al. 2002). 


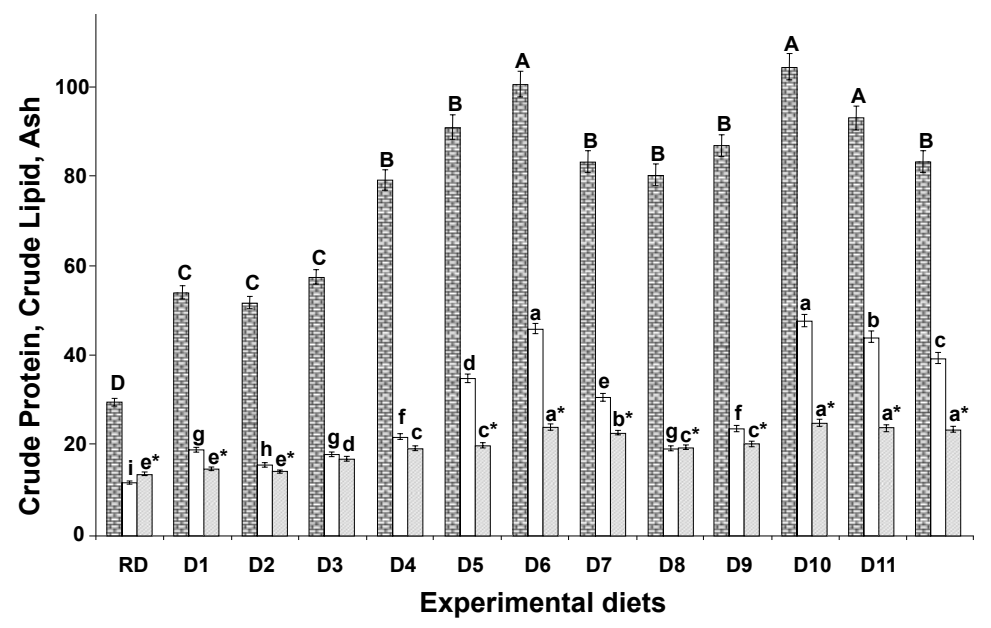

Fig. 3. Proximate carcass composition (\% wet weight; crude protein, crude lipid, ash) of Labeo rohita fingerlings at the start and end of the 80 day feeding experiment; Values are mean \pm standard error of the mean; Error bars show deviation among three replicates; Means with different letters are significantly different $(P<0.05)$; Experimental diets and respective phytase content $\left[\mathrm{FTU} \cdot \mathrm{kg}^{-1}\right]: \mathrm{D} 2=10, \mathrm{D} 3=20, \mathrm{D} 4=30, \mathrm{D} 5=40 ; \mathrm{D} 6=50, \mathrm{D} 7=10, \mathrm{D} 8=20$, $\mathrm{D} 9=30, \mathrm{D} 10=40, \mathrm{D} 11=50 ;[1 \mathrm{FTU}$ is defined as the amount of phytase that liberates $1 \mu \mathrm{mol}$ of inorganic phosphorus from $0.0051 \mathrm{~mol} \cdot \mathrm{L}^{-1}$ of sodium phytate per min at $37^{\circ} \mathrm{C}$ and $\mathrm{pH} 5.5$ ]

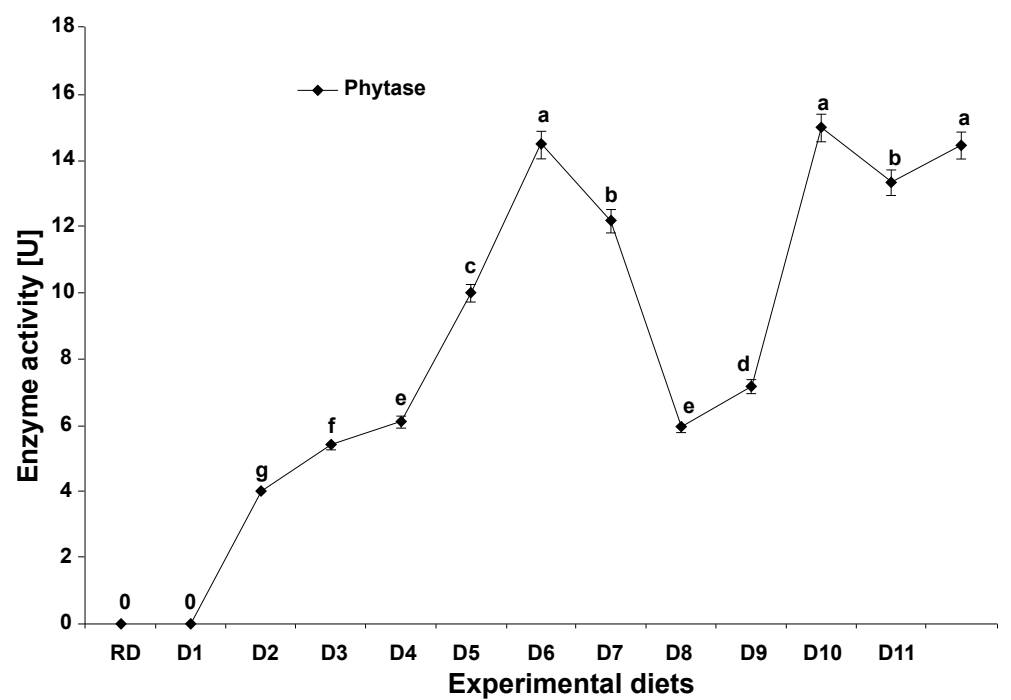

Fig. 4. Intestinal phytase activity of Labeo rohita fingerlings fed experimental diets for 80 days; Values are mean \pm standard error of the mean; Error bars show deviation among three replicates; Means with different letters are significantly different $(P<0.05)$; Experimental diets and respective phytase content $\left[\mathrm{FTU} \cdot \mathrm{kg}^{-1}\right]$ : D2 $=10, \mathrm{D} 3=20$, $\mathrm{D} 4=30, \mathrm{D} 5=40 ; \mathrm{D} 6=50, \mathrm{D} 7=10, \mathrm{D} 8=20, \mathrm{D} 9=30, \mathrm{D} 10=40, \mathrm{D} 11=50 ;[1 \mathrm{FTU}$ is defined as the amount of phytase that liberates $1 \mu \mathrm{mol}$ of inorganic phosphorus from $0.0051 \mathrm{~mol} \cdot \mathrm{L}^{-1}$ of sodium phytate per min at $37^{\circ} \mathrm{C}$ and $\mathrm{pH}$ 5.5]

In the presently reported experiment, $\mathrm{pH}$ of the experimental diets was maintained at 5.5 by adding citric acid. Several studies reported that microbial phytase has two optimal peaks of activity, one at $\mathrm{pH} 5.0-5.5$ and the other at pH 2.5 (Simons et al. 1990). On the other hand, phytase activity changes along the digestive tract (Yi and Kornegay 1996). There are some evidences that $\mathrm{pH}$ of the gastrointestinal tract affects the bioavailability of minerals in fish (Sugiura et al. 1998, Vielma et al. 1999). In addition to their effect on intestinal $\mathrm{pH}$, supplementary organic acids can also bind various cations along the intestine (Ravindran and Kornegay 1993), resulting in increased intestinal absorption of minerals (Sugiura et al. 1998,
Vielma et al. 1999). Citric acid has been reported to increase $\mathrm{P}$ bioavailability by dephosphorylation of phytate in vitro (Żyła et al. 1995). Baruah et al. (2007a, 2007b,) and Sugiura et al. (2001) also reported that addition of citric acid into the fish feed increased $\mathrm{P}$ utilization in Labeo rohita juveniles and also apparent absorption of $\mathrm{Mg}$ and $\mathrm{P}$ in Oncorhynchus mykiss, respectively. In carnivorous fish like rainbow trout, production of acids assist in lowering the dietary $\mathrm{pH}$, but in agastric species like L. rohita, no such mechanism exists. Hence, addition of organic acids or acidifiers may reduce the dietary $\mathrm{pH}$, which in turn may reduce the $\mathrm{pH}$ of the intestine and enhance mineral absorption. Further, dietary acidification may reduce 


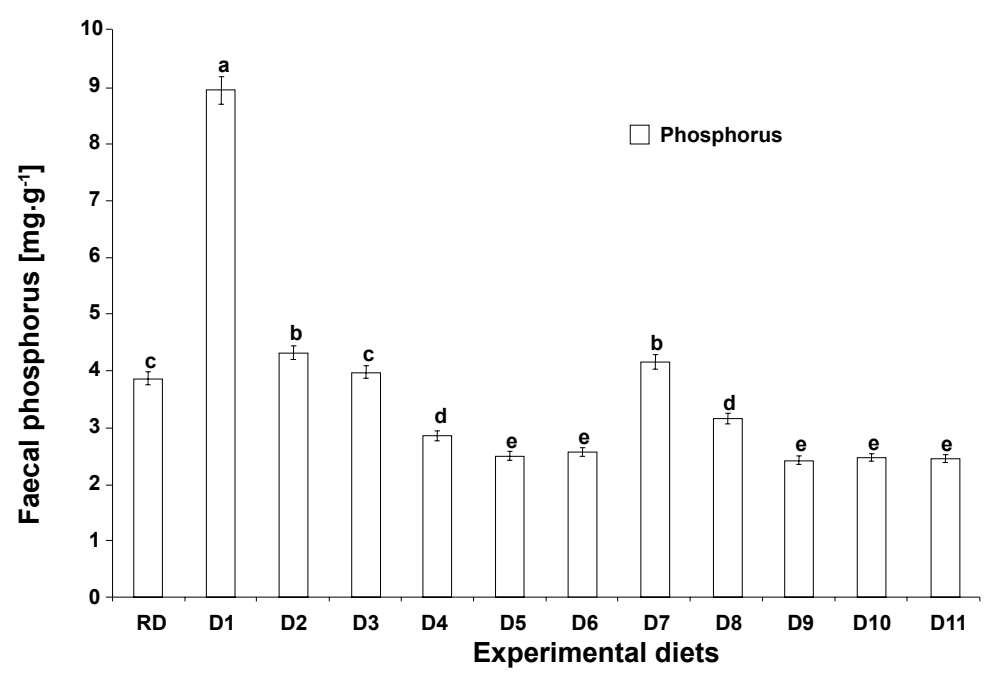

Fig. 5. Faecal phosphorus concentration of Labeo rohita fingerlings fed experimental diets for 80 days; Values are mean \pm standard error of the mean; Error bars show deviation among three replicates; Means with different letters are significantly different $(P<0.05)$; Experimental diets and respective phytase content $\left[\mathrm{FTU} \cdot \mathrm{kg}^{-1}\right]: \mathrm{D} 2=10$, $\mathrm{D} 3=20, \mathrm{D} 4=30, \mathrm{D} 5=40 ; \mathrm{D} 6=50, \mathrm{D} 7=10, \mathrm{D} 8=20, \mathrm{D} 9=30, \mathrm{D} 10=40, \mathrm{D} 11=50 ;[1 \mathrm{FTU}$ is defined as the amount of phytase that liberates $1 \mu \mathrm{mol}$ of inorganic phosphorus from $0.0051 \mathrm{~mol} \cdot \mathrm{L}^{-1}$ of sodium phytate per min at $37^{\circ} \mathrm{C}$ and $\mathrm{pH}$ 5.5]

the rate of gastric emptying (Mayer 1994), which may favour the action of phytase. Thus, it was hypothesized that dietary addition of organic acids and microbial phytase has a synergistic effect on mineral availability. In the presently reported study, the significant increase in growth parameters, body protein accretion, nutrient (crude protein, lipid), and mineral digestibility may be due to the synergistic effect of dietary addition of organic acid (citric acid) and microbial phytase.

Study of digestive enzymes is an essential step towards understanding the mechanism of digestion and how the organism adapts to changes in the nutritional environment (Xue et al. 1999). The gut (endogenous) phytase enzyme is the indicator of digestibility and utilization of nutrients and minerals. In this experiment, intestinal phytase activity was found to increase with increasing level of incorporation of phytase. In the presently reported study, the endogenous phytase activity was estimated in the fish intestine fed phytase pre-treated diets in order to compare the activity among the groups of fish fed bacterial and commercial phytase. Therefore, endogenous phytase activity was not estimated at initial stage as well as in the group of fish fed $\mathrm{RD}$. Intestinal phytase activity was higher in the group of fish fed phytase pretreated diets in comparison to those fed on raw oilseed meal incorporated diets. It therefore, appears that pretreatment i.e., fermentation might have played an important role in enhancement of intestinal phytase activity.

In the presently reported study, the faecal phosphorus concentration was significantly higher in fish fed raw sesame oilseed meal incorporated diets than the reference diet and an increasing level of phytase pre-treated SOM was associated with a decrease in faecal phosphorus concentration. Maximum faecal phosphorus concentration was found in the fish fed diet D1. The results of the present study indicate that reduction of $\mathrm{P}$ wastes could be accomplished by the incorporation of phytase in diets due to improved utilization of dietary phytin P. These findings are in agreement with the findings of previous workers who reported that phytase pre-treatment increases the utilization of dietary nutrients and minerals and also reduces pollution in aquatic environment by decreasing excretion of phosphorus and protein through faeces (Nwanna and Schwarz 2007, Sardar et al. 2007, Laining et al. 2012, Liu et al. 2012).

\section{CONCLUSION AND FUTURE PERSPECTIVES}

In conclusion, these results support the hypothesis that phytase (Biophos-TS and from fish gut bacteria Bacillus licheniformis) pre-treated diets containing high levels of plant feedstuffs will reduce the excretion of waste $P$ thereby resulting in reduced $\mathrm{P}$ effluent from aquaculture facilities. On the other hand, pre-treatment of diets with phytase may not only enhance the utilization of phosphorus but also other nutrients including protein and amino acids. Comparison of the efficacy of phytase produced by fish gut bacteria with commercially available phytase (Biophos-TS) indicated no significant difference in terms of growth rate, proximate carcass composition, apparent nutrient and mineral digestibility. Thus, preparation of fish feed by fermented with phytase produced by fish gut bacteria and commercial phytase may be expected to provide both economic and environmental benefits through decreased expenditures on supplemental minerals and mineral outputs to the aquatic ecosystem. However, it is too early to recommend to the industry to use the phytase pre-treated SOM in formulation of aquafeeds. The costs involved in phytase pre-treatment have yet to be justified. Further research is necessary in this direction to evaluate the efficacy of the pre-treatment strategy and the economic benefits of utilizing these products in aquafeeds. 


\section{ACKNOWLEDGEMENTS}

We are grateful to the Indian Council of Agricultural Research, New Delhi, (Project No. F.4(26)/2004-ASR-I) for financial support. We gratefully acknowledge Dr. Sudhakar Reddy, In charge, Overseas Operations, Biochem Health Care, Mumbai, India, for free gift of Biophos-TS for our experimental work. There is no conflict of interest among the authors and Biochem Health Care, Mumbai, India.

\section{REFERENCES}

Afinah S., Yazid A.M., Shobirin Anis M.H., Shuhaimi M. 2010. Phytase: Application in food industry. International Food Research Journal 17 (1): 13-21.

Anonymous 1985. Standard methods for the examination of water and waste water. 16th edition. American Public Health Association, American Water Works Association and Water Pollution Control Federation, Washington, DC, USA.

Anonymous 1990. Official methods of analysis. 15th edn. Association of Official Analytical Chemists (AOAC), Washington, DC, USA.

Anonymous 1993. Nutrient requirements of fish. Committee on Animal Nutrition, Board on Agriculture. National Research Council (NRC), National Academy Press, Washington, DC, USA.

Bairagi A., Sarkar Ghosh K., Sen S.K., Ray A.K. 2002. Duckweed (Lemna polyrhiza) leaf meal as a source of feedstuff in formulated diets for rohu (Labeo rohita Ham.) fingerlings after fermentation with a fish intestinal bacterium. Bioresource Technology 85 (1): 17-24. DOI: $10.1016 / \mathrm{s} 0960-8524(02) 00067-6$

Bairagi A., Sarkar Ghosh K., Sen S.K., Ray A.K. 2004. Evaluation of nutritive value of Leucaena leucocephala leaf meal, inoculated with fish intestinal bacteria Bacillus subtilis and Bacillus circulans in formulated diets for rohu, Labeo rohita (Hamilton) fingerlings. Aquaculture Research 35 (5): 436-446.

DOI: $10.1111 /$ j.1365-2109.2004.01028.x

Baruah K., Pal A.K., Sahu N.P., Debnath D. 2007a. Microbial phytase supplementation in rohu, Labeo rohita, diets enhances growth performance and nutrient digestibility. Journal of the World Aquaculture Society 38 (1): 129-137.

DOI: $10.1111 /$ j.1749-7345.2006.00081.x

Baruah K., Sahu N.P., Pal A.K., Debnath D., Yengkokpam S. 2007b. Interactions of dietary microbial phytase, citric acid and crude protein level on mineral utilization by rohu, Labeo rohita (Hamilton), juveniles. Journal of the World Aquaculture Society 38 (2): 238-249.

DOI: $10.1111 / \mathrm{j} .1749-7345.2007 .00092 . x$

Benkappa S., Varghese T.J. 2003. Isoleucine, leucine, and valine requirement of juvenile Indian major carp, Cirrhinus cirrhosus (Bloch, 1795). Acta Ichthyologica et Piscatoria 33 (2): 161-172.

DOI: 10.3750/AIP2003.33.2.06
Cao L., Wang W., Yang C., Yang Y., Diana J., Yakupitiyage A., Luo Z., Li D. 2007. Application of microbial phytase in fish feed. Enzyme and Microbial Technology 40 (4): 497-507.

DOI: $10.1016 /$ j.enzmictec.2007.01.007

Cao L., Yang Y., Wang W.M., Yakupitiyage A., Yuan D.R., Diana J.S. 2008. Effects of pretreatment with microbial phytase on phosphorus utilization and growth performance of Nile tilapia (Oreochromis niloticus). Aquaculture Nutrition 14 (2): 99-109.

DOI: $10.1111 /$ j.1365-2095.2007.00508.x

Carter C.G., Sajjadi M. 2011. Low fishmeal diets for Atlantic salmon, Salmo salar L., using soy protein concentrate treated with graded levels of phytase. Aquaculture International 19 (3): 431-444.

DOI: $10.1007 / \mathrm{s} 10499-010-9358-\mathrm{z}$

Das P., Ghosh K. 2015. Improvement of nutritive value of sesame oil cake in formulated diets for rohu, Labeo rohita (Hamilton) after bio-processing through solid state fermentation by a phytase-producing fish gut bacterium. International Journal of Aquatic Biology 3 (2): 89-101.

Debnath D., Pal A.K., Sahu N.P., Jain K.K., Yengkokpam S., Mukherjee S.C. 2005. Effect of dietary microbial phytase supplementation on growth and nutrient digestibility of Pangasius pangasius (Hamilton) fingerlings. Aquaculture Research 36 (2): 180-187. DOI: 10.1111/j.1365-2109.2004.01203.x

Du Z.-Y., Liu Y.-J., Tian L.-X., He J.-G., Cao J.-M., Liang G.-Y. 2006. The influence of feeding rate on growth, feed efficiency and body composition of juvenile grass carp (Ctenopharyngodon idella). Aquaculture International 14 (3): 247-257. DOI: $10.1007 / \mathrm{s} 10499-005-9029-7$

Duncan D.B. 1955. Multiple range and multiple $F$ tests. Biometrics 11 (1): 1-42. DOI: $10.2307 / 3001478$

Engelen A.J., van der Heeft F.C., Randsdorp P.H.G., Smit E.L.C. 1994. Simple and rapid determination of phytase activity. Journal of AOAC International 77 (3): 760-764.

Forster I., Higgs D.A., Dosanjh B.S., Rowshandeli M., Parr J. 1999. Potential for dietary phytase to improve the nutritive value of canola protein concentrate and decrease phosphorus output in rainbow trout (Oncorhynchus mykiss) held at $11^{\circ} \mathrm{C}$ fresh water. Aquaculture 179 (1-4): 109-125.

DOI: $10.1016 / \mathrm{S} 0044-8486(99) 00156-8$

Fry F.E.J. 1971. [1] The effect of environmental factors on the physiology of fish. Pp. 1-99.

DOI: 10.1016/S1546-5098(08)60146-6. In: Hoar W.S., Randall D.J. (eds.) Fish physiology, Vol. VI. Academic Press, New York and London.

Gatlin III D.M., Li P. 2008. [17] Use of diet additives to improve nutritional value of alternative protein sources. Pp. 501-522. In: Lim C., Lee C.-S., Webster C.D. (eds.) Alternative protein sources in aquaculture diets. CRC Press, Boca Raton, FL, USA. 
Hardy R.W. 2010. Utilization of plant proteins in fish diets: Effects of global demand and supplies of fishmeal. Aquaculture Research 41 (5): 770-776. DOI: $10.1111 /$ j.1365-2109.2009.02349.x

Hardy R.W., Barrows F.T. 2008. [9] Diet formulation and manufacture. Pp. 505-600. DOI: 10.1016/B978-012319652-1/50010-0. In: Halver J.E., Hardy R. (eds.) Fish nutrition. 3rd edn. Academic Press, San Diego, CA, USA.

Hassaan M.S., Soltan M.A., Agouz H.M., Badr A.M. 2013. Influences of calcium/phosphorus ratio on supplemental microbial phytase efficiency for Nile tilapia (Oreochromis niloticus). Egyptian Journal of Aquatic Research 39 (3): 205-213.

DOI: 10.1016/j.ejar.2013.09.001

Hauler R.C., Carter C.G. 1997. [2] Phytase stimulates appetite in Atlantic salmon (Salmo salar L.) parr fed soybean meal. The Proceedings of Nutrition Society of Australia 21: 139.

Hawk P.B. 1960. Hawk's physiological chemistry. Tata McGraw-Hill Publishing, New Delhi, India.

Huang H., Shao N., Wang Y., Luo H., Yang P., Zhou Z., Zhan Z., Yao B. 2009. A novel beta-propeller phytase from Pedobacter nyackensis MJ11 CGMCC 2503 with potential as an aquatic feed additive. Applied Microbiology and Biotechnology 83 (2): 249-259. DOI: $10.1007 / \mathrm{s} 00253-008-1835-1$

Hung S.S.O., Lutes P.B. 1987. Optimum feeding rate of hatchery-produced juvenile white sturgeon (Acipenser transmontanus): at $20^{\circ} \mathrm{C}$. Aquaculture 65 (3-4): 307317.

DOI: $10.1016 / 0044-8486(87) 90243-2$

Hussain S.M., Rana S.A., Afzal M., Shahid M. 2011. Efficacy of phytase supplementation on mineral digestibility in Labeo rohita fingerlings fed on corn gluten meal $(30 \%)$ based diets. Pakistan Journal of Agricultural Sciences 48 (3): 237-241.

Huynh H.P.V., Nugegoda D. 2011. Effects of dietary supplements on growth performance and phosphorus waste production of Australian catfish, Tandanus tandanus, fed with diets containing soybean meal as fishmeal replacement. Journal of the World Aquaculture Society 42 (5): 645-656.

DOI: $10.1111 / \mathrm{j} .1749-7345.2011 .00505 . x$

Islam M.S. 2002. Evaluation of supplementary feed for semi-intensive pond culture of mahseer, Tor putitora (Hamilton). Aquaculture 212 (1-4): 263-276. DOI: $10.1016 / \mathrm{S} 0044-8486(02) 00194-1$

Khan A., Ghosh K. 2012. Characterization and identification of gut-associated phytase-producing bacteria in some fresh water fish cultured in ponds. Acta Ichthyologica et Piscatoria 42 (1): 37-45. DOI: 10.3750/AIP2011.42.1.05

Khan A., Ghosh K. 2013. Phytic acid-induced inhibition of digestive protease and $\alpha$-amylase in three Indian major carps: An in vitro study. Journal of the World Aquaculture Society 44 (6): 853-859.

DOI: $10.1111 /$ jwas. 12084
Khan N., Ashraf M., Aziz Qureshi N., Sarker P.K., Vandenberg G.W., Rasool F. 2012. Effect of similar feeding regime on growth and body composition of Indian major carps (Catla catla, Cirrhinus mrigala and Labeo rohita) under mono and polyculture. African Journal of Biotechnology 11 (44): 10280-10290. DOI: $10.5897 / A J B 11.4023$

Krogdahl Å., Penn M., Thorsen J., Refstie S., Bakke A.M. 2010. Important antinutrients in plant feedstuffs for aquaculture: An update on recent findings regarding responses in salmonids. Aquaculture Research 41 (3): 333-344. DOI: $10.1111 /$ j.1365-2109.2009.02426.x

Laining A., Ishikawa M., Koshio S., Lideman, Yokoyama S. 2012. Dietary inorganic phosphorus or microbial phytase supplementation improves growth, nutrient utilization and phosphorus mineralization of juvenile red sea bream, Pagrus major, fed soybeanbased diets. Aquaculture Nutrition 18 (5): 502-511. DOI: $10.1111 /$ j.1365-2095.2011.00914.x

Li M.H., Robinson E.H. 1997. Microbial phytase can replace inorganic phosphorus supplements in channel catfish Ictalurus punctatus diets. Journal of the World Aquaculture Society 28 (4): 402-406.

DOI: $10.1111 /$ j.1749-7345.1997.tb00287.x

Liebert F., Portz L. 2005. Nutrient utilization of Nile tilapia Oreochromis niloticus fed plant based low phosphorus diets supplemented with graded levels of different sources of microbial phytase. Aquaculture 248 (1-4): 111-119.

DOI: $10.1016 /$ j.aquaculture.2005.04.009

Liu L., Su J., Luo Y. 2012. Effect of partial replacement of dietary monocalcium phosphate with neutral phytase on growth performance and phosphorus digestibility in gibel carp, Carassius auratus gibelio (Bloch). Aquaculture Research 43 (9): 1404-1413.

DOI: $10.1111 / \mathrm{j} .1365-2109.2011 .02944 . \mathrm{X}$

Liu L., Su J., Liang X.-F., Luo Y. 2013. Growth performance, body lipid, brood amount, and rearing environment response to supplemental neutral phytase in zebrafish (Danio rerio) diet. Zebrafish 10 (3): 433-438. DOI: 10.1089/zeb.2012.0853

Lovell T. 1998. [7] Fish nutrition and feeding experiments. Pp. 123-134.

DOI: 10.1007/978-1-4615-4909-3_7. In: Lovell T. (ed.) Nutrition and feeding of fish. $\overline{2}$ nd edn. Springer Science + Business Media, New York, NY, USA. DOI: $10.1007 / 978-1-4615-4909-3$

Mayer E.A. 1994. The physiology of gastric storage and emptying. Pp. 929-976. In: Johnson L.R., Alpers D.H., Christensen J., Jacobsen E. (eds.) Physiology of the gastrointestinal tract. 3rd edn. Lippencott Raven Press, New York, NY, USA.

Morales G.A., Márquez L., Saenz de Rodrigañez M., Bermúdez L., Robles R., Moyano F.J. 2014. Effect of phytase supplementation of a plant-based diet on phosphorus and nitrogen bioavailability in sea bream Sparus aurata. Aquaculture Nutrition 20 (2): 172-182. DOI: 10.1111/anu.12063 
Nang Thu T.T., Bodin N., de Saeger S., Larondelle Y., Rollin X. 2011. Substitution of fish meal by sesame oil cake (Sesamum indicum L.) in the diet of rainbow trout (Oncorhynchus mykiss W.). Aquaculture Nutrition 17 (1): 80-89. DOI: $10.1111 / \mathrm{j} .1365-2095.2009 .00732 . x$

Nwanna L.C., Schwarz .FJ. 2007. Effect of supplemental phytase on growth, phosphorus digestibility and bone mineralization of common carp (Cyprinus carpio L). Aquaculture Research 38 (10): 1037-1044.

DOI: $10.1111 / \mathrm{j} .1365-2109.2007 .01752 . x$

Nwanna L.C., Schwarz F., Broz J. 2005. Influence of phytase and incubation of plant feedstuffs on growth and phosphorus digestibility by common carp (Cyprinus carpio). Applied Tropical Agriculture 10: 101-108.

Oliva-Teles A., Pereira J.P., Gouveia A., Gomes E. 1998. Utilization of diets supplemented with microbial phytase by seabass (Dicentrarchus labrax) juveniles. Aquatic Living Resources 11 (4): 255-259.

DOI: $10.1016 / \mathrm{s} 0990-7440(98) 80008-9$

Papatryphon E., Soares jr. J.H. 2001.The effect of phytase on apparent digestibility of four practical plant feedstuffs fed to striped bass, Morone saxatilis. Aquaculture Nutrition 7 (3): 161-167.

DOI: 10.1046/j.1365-2095.2001.00174.x

Pörtner H.O. 2001. Climatic change and temperaturedependent biogeography: Oxygen limitation of thermal tolerance in animals. Naturwissenschaften $\mathbf{8 8}$ (4): 137-146.

Rajendran S., Prakash V. 1993. Kinetics and thermodynamics of the mechanism of interaction of sodium phytate with $\alpha$-globulin. Biochemistry 32 (13): 3474-3478.

DOI: $10.1021 / \mathrm{bi00064a035}$

Ramachandran S., Ray A.K. 2007. Nutritional evaluation of fermented black gram (Phaseolus mungo) seed meal in compound diets for rohu, Labeo rohita (Hamilton), fingerlings. Journal of Applied Ichthyology 23 (1): 74-79.

DOI: $10.1111 / \mathrm{j} .1439-0426.2006 .00772 . x$

Rao D.E.C.S., Rao K.V., Reddy T.P., Reddy V.D. 2009. Molecular characterization, physicochemical properties, known and potential applications of phytases: An overview. Critical Reviews in Biotechnology 29 (2): 182-198.

DOI: $10.1080 / 07388550902919571$

Ravi J., Devaraj K.V. 1991. Quantitative essential amino acid requirements for growth of catla, Catla catla (Hamilton). Aquaculture 96 (3-4): 281-291.

DOI: 10.1016/0044-8486(91)90158-4

Ravindran V., Kornegay E.T. 1993. Acidification of weaner pig diets: A review. Journal of the Science of Food and Agriculture 62 (4): 313-322.

DOI: $10.1002 /$ jsfa. 2740620402

Roy T., Banerjee G., Dan S.K., Ghosh P., Ray A.K. 2014. Improvement of nutritive value of sesame oilseed meal in formulated diets for rohu, Labeo rohita (Hamilton), fingerlings after fermentation with two phytase-producing bacterial strains isolated from fish gut. Aquaculture International 22 (2): 633-652.

DOI: $10.1007 / \mathrm{s} 10499-013-9691-0$

Roy T., Banerjee G., Dan S.K., Ray A.K. 2013. Optimization of fermentation conditions for phytase production by two strains of Bacillus licheniformis (LF1 and LH1) isolated from the intestine of rohu, Labeo rohita (Hamilton). Proceedings of the Zoological Society 66 (1): 27-35.

DOI: $10.1007 / \mathrm{s} 12595-012-0057-9$

Roy T., Mondal S., Ray A.K. 2009. Phytase-producing bacteria in the digestive tracts of some freshwater fish. Aquaculture Research 40 (3): 344-353.

DOI: $10.1111 /$ j.1365-2109.2008.02100.x

Sardar P., Randhawa H.S., Abid M., Prabhakar S.K. 2007. Effect of dietary microbial phytase supplementation on growth performance, nutrient utilization, body compositions and haemato-biochemical profiles of Cyprinus carpio (L.) fingerlings fed soyprotein-based diet. Aquaculture Nutrition 13 (6): 444-456.

DOI: $10.1111 /$ j.1365-2095.2007.00497.x

Schanderi S.H. 1970. Method in food analysis. Academic Press, New York.

Simons P.C.M., Versteegh H.A.J., Jongbloed A.W., Kemme P.A., Slump P., Bos K.D., Wolters, M.G.E., Beudeker R.F., Verschoor G.J. 1990. Improvement of phosphorus availability by microbial phytase in broilers and pigs. British Journal of Nutrition 64 (2): 525-540.

DOI: $10.1079 /$ bjn 19900052

Spyridakis P., Metailler R., Gabaudan J., Riaza A. 1989. Studies on nutrient digestibility in European sea bass (Dicentrarchus labrax). 1. Methodological aspects concerning faeces collection. Aquaculture 77 (1): 61-70.

DOI: 10.1016/0044-8486(89)90021-5

Steffens W. 1989. Principles of fish nutrition. Ellis Horwood, Chichester.

Storebakken T., Shearer K.D., Roem A.J. 1998. Availability of protein, phosphorus and other elements in fish meal, soy-protein concentrate and phytasetreated soy-protein-concentrate-based diets to Atlantic salmon, Salmo salar. Aquaculture 161 (1-4): 365-379. DOI: $10.1016 / \mathrm{s} 0044-8486(97) 00284-6$

Sugiura S.H., Dong F.M., Hardy R.W. 1998. Effect of dietary supplements on the availability of minerals in fish meal: Preliminary observations. Aquaculture $\mathbf{1 6 0}$ (3-4): 283-303.

DOI: $10.1016 / \mathrm{s} 0044-8486(97) 00302-5$

Sugiura S.H., Gabaudan J., Dong F.M., Hardy R.W. 2001. Dietary microbial phytase supplementation and the utilization of phosphorus, trace minerals and protein by rainbow trout [Oncorhynchus mykiss (Walbaum)] fed soybean meal-based diets. Aquaculture Research 32 (7): 583-592.

DOI: $10.1046 / j .1365-2109.2001 .00581 . x$ 
Vielma J., Ruohonen K., Lall S.P. 1999. Supplemental citric acid and particle size of fish bone-meal influence the availability of minerals in rainbow trout Oncorhynchus mykiss (Walbaum). Aquaculture Nutrition 5 (1): 65-71.

DOI: $10.1046 /$ j.1365-2095.1999.00092.X

Wheeler E.L., Ferrel R.E. 1971. A Method for phytic acid determination in wheat and wheat fractions. Cereal Chemistry 48: 312-320.

Xue X.M., Anderson A.J., Richardson N.A., Anderson A.J., Xue G.P., Mather P.B. 1999. Characterisation of cellulase activity in the digestive system of the redclaw crayfish (Cherax quadricarinatus). Aquaculture $\mathbf{1 8 0}$ (3-4): 373-386.

DOI: 10.1016/s0044-8486(99)00213-6

Yan W., Reigh R.C., Xu Z. 2002. Effects of fungal phytase on utilization of dietary protein and minerals, and dephosphorylation of phytic acid in the alimentary tract of channel catfish Ictalurus punctatus fed an allplant protein diet. Journal of the World Aquaculture Society 33 (1): 10-22.

DOI: $10.1111 /$ j.1749-7345.2002.tb00473.X

Yang Y.-H., Wang Y.-Y., Lu Y., Li Q.-Z. 2011. Effect of replacing fish meal with soybean meal on growth, feed utilization and nitrogen and phosphorus excretion on rainbow trout (Oncorhynchus mykiss). Aquaculture International 19 (3): 405-419.

DOI: $10.1007 / \mathrm{s} 10499-010-9359-y$
Yi Z., Kornegay E.T. 1996. Sites of phytase activity in the gastrointestinal tract of young pigs. Animal Feed Science and Technology 61 (1-4): 361-368. DOI: 10.1016/0377-8401(96)00959-5

Yoo G., Bai S.C. 2014. Effects of the dietary microbial phytase supplementation on bioavailability of phosphorus in juvenile olive flounder Paralichthys olivaceus fed soybean meal based diets. Fisheries and Aquatic Sciences 17 (3): 319-324.

DOI: $10.5657 /$ FAS.2014.0319

Yoo G.Y., Wang X.J., Choi S.M., Han K., Kang J.-C., Bai S.C. 2005. Dietary microbial phytase increased the phosphorus digestibility in juvenile Korean rockfish Sebastes schlegeli fed diets containing soybean meal. Aquaculture 243 (1-4): 315-322.

DOI: $10.1016 /$ j.aquaculture.2004.10.025

Zhu Y., Qiu X., Ding Q., Duan M., Wang C. 2014. Combined effects of dietary phytase and organic acid on growth and phosphorus utilization of juvenile yellow catfish Pelteobagrus fulvidraco. Aquaculture 430: 1-8. DOI: $10.1016 /$ j.aquaculture.2014.03.023

Żyła K., Ledoux D.R., Garcia A., Veum T.L. 1995. An in vitro procedure for studying enzymic dephosphorylation of phytate in maize-soyabean feeds for turkey poults. British Journal of Nutrition 74 (1): 3-17.

DOI: $10.1079 /$ bjn19950102

Received: 7 September 2015

Accepted: 15 March 2016

Published electronically: 31 March 2016 